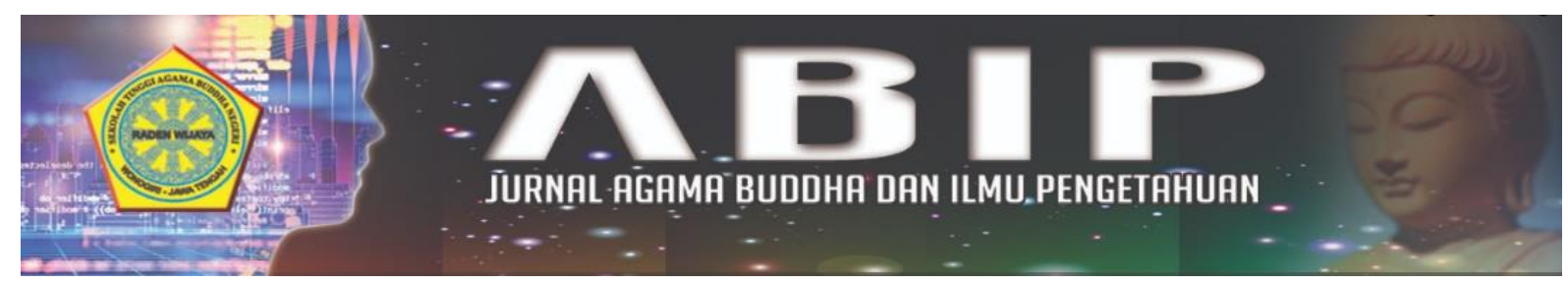

\title{
WEB-BLOG TO ENCOURAGES WRITING SKILL
}

\author{
By: \\ Moh Hafidz \\ STKIP PGRI Bangkalan \\ mohhafidz@stkippgri-bkl.ac.id
}

\begin{abstract}
Writing is exploring some ideas in online media in academically texts . In this study, the researcher statistically examines Web-log to encourage Students' Writing Skills. This research uses quasiexperimental research designs with non-equivalent groups pretest-posttest. There are experimental and control group. these groups are given in different treatments. the experimental group is taught using Web-log media and the control group is textbook. The population of this research is eleventh grade students of SMAN Bangkalan in the. The number of subjects was 46 students. Data obtained by conducting essay writing tests (pre and post tests) in class XI- 4 (experimental) and class XI- 5 (control group). The result of test are analyzed by using covariate analysis (ANCOVA). The results show that the P-value score (0.16) $<0.05$ (alpha). It means that the hypothesis $(\mathrm{HO})$ is rejected and (Ha) is accepted. from these results, there are significant differences in student grades. Therefore, the students who are taught using the Web-log on writing have better scores than students who are taught using textbook media, the most significant effect of Web-log media on writing skill is on the generic structure aspect.
\end{abstract}

Key words: Web-Blog, Media, Writing Skill

\section{INTRODUCTION}

Learning environment of English teaching has some crucial issues to due the learner autonomous context. Learner autonomy are able to formulates the whole of learning process to student's central learning, the student's expectation is the main basic of designing the syllaby and considering the developed external causes which support the purposes of its syllaby to lecture the students communicatively in inside and outside the classroom (Little, 1999). Learner autonomy absolutely denies the limitation of learing and constructs the long life learning for students in writing skill. In contrast, most of students have traditional poit of view that learning is an administrative interaction in the class and do the tasks in instruction based only. While, the technology is part of the student's life.

The advanced of technology (Webblog) truly brings the students to learn independently in the wide class, it dominantly effects on student's pedagogical aspect such as using technology as a tool of searching knowledge and drilling skill, and psychological aspects such as stress and frustation without internet acces in learning (Lee, 2011). It also opens the students to learn more outside the class.

The psychological effect of technology relates with the self-competence which encourages individually making decisions when the students get some problems in learning process. The good personality will eazily control the emotion, undertand what sould they want to learn and appropiate skill they have to drill (Künne, 2012). Sometimes, the student's worried in some mistakes distrubs the focus of subject matters especially in writing skill.

Beside, the subject metter of writing becomes the individual challange to begin 
each step in writing technique because of background knowledge and habitual behave to write. The most student's problems of writing are how to outline the writing, make actual content, utilize the aspects and good mechanics of writing (Karsak, 2014). In these cases, students are expected to learn whole aspects that motivate students to be a good writers.

The conclude, the media emphasizes on the student's learning experience and learning objectives those are systematically managed in solving the their own writing problem though web-blog. The objectives of this study is how do the Web-Blog encourage to student's writing skill?.

\section{METHODOLOGY}

In this research, the researcher used quantitative research in quasi-experimental design to find out whether there are significant differences in the writing skill between students who using Web-log with students who were taught regular literacy curriculum writing skills. Researcher only assign different treatments randomly to two different classes. Furthermore, the different treatments was applied randomly by researchers for two different classes (Latief, 2016). Therefore the design of this study only used two groups to be tested. One class as the experimental group and one class as the control group, where each group was given a pre-test and post-test.

The population of this study used all of the students of class XI IPA of SMAN Bangkalan in the second semester consisting of XI IPA, XI IPA 2, XI IPA 3, XI IPA 4 and XI IPA 5 consisting of 115 students. Samples ware selected from two classes that have almost the same quality to be divided into two groups. The first group was the experimental group and the second group was the control group. The experimental group was treated by using Web-log on writing, while the control group was given textbook writing activities.

Then, the test was used as an instrument in this study such as short answer essays, essay writing, problem solving and performance test items (Rudasill, 2011). The form of test to be used is a written paragraph. Tests were given to students in the pre-test and post-test. Pre-tests were given to two groups that were selected as samples before treatment and post-test.

Validity and Reliability

The content used in this study was the content of validity with the scope of the assignment being evidence or sample by consulting with experts (English teacher in SMAN Bangkalan).

The test was reliabile if the same test was given to the ssimiliar subject on different occasions. So, the value in the test must be positive that high and reliable result is a measuring instrument. Latief (2014) stated reliability is the consistency of the final value of the assessment. It means that data was declared to have reliability if the test results remain consistent even if repeated on different occasions. To analyze and assess reliability, researcher also use SPSS (statistical package for social sciences) for windows 23 programs.

After obtaining the data from the pretest and post-test, the researcher analyzed and process the data using the SPSS formula (Statistical Package for the Social Science) 23 and the researcher used ANCOVA to analyze the data.

\section{RESULT AND DISCUSSION}

Instrument Validity Result

The content validity was used by the researcher to validate research instruments. The instrument was valid before being given to the sample and completing the rules item by the expert judgment.

Table 1 Descriptive Statistics

\begin{tabular}{|l|c|r|r|}
\hline & Mean & Std. Deviation & $\mathrm{N}$ \\
\hline Test & 67.32 & 8.877 & 25 \\
Rest & 74.08 & 6.855 & 25 \\
\hline
\end{tabular}

Table 2 Correlations

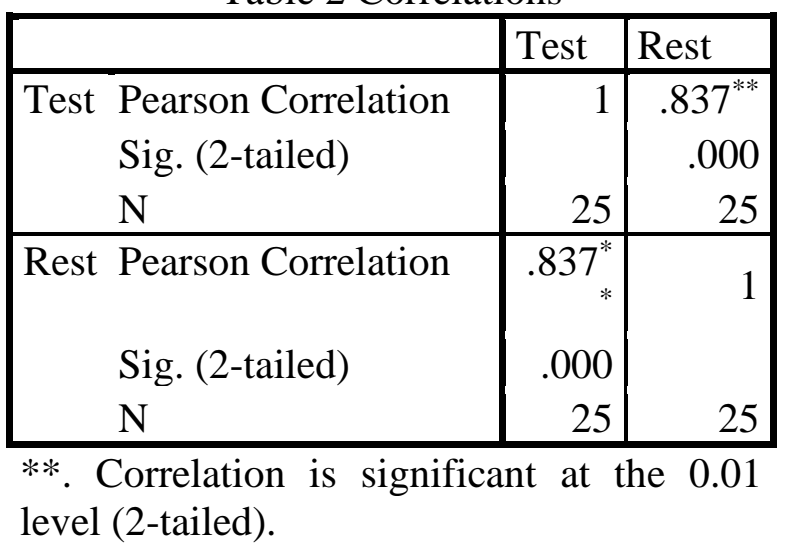


Based on table 4.2, it can be seen that the results of the Pearson Product Moment correlation coefficient show as big as 0.837 . It means that the proof of the reliability of the instrument using retesting is quite reliable.

The Result of Analysis of Variance (ANCOVA)

Table 3 Between-Subjects Factors

\begin{tabular}{|ll|l|l|}
\hline & & Value Label & $\mathrm{N}$ \\
\hline Media & 1 & Experimental & 23 \\
& 2 & Control & 23 \\
\hline
\end{tabular}

1. The sample of experimental group taught by using online newspaper is 23 .

2. The sample of control group taught by using textbook is 23 .

Table 4. Levene's Test of Equality of Error Variances $^{\mathrm{a}}$

Dependent Variable: Writing

\begin{tabular}{|c|c|c|c|}
\hline$F$ & df1 & df2 & Sig. \\
\hline 142 & 1 & 44 & .708 \\
\hline
\end{tabular}

Tests the null hypothesis that the error variance of the dependent variable is equal across groups.

a. Design: Intercept + Pretest + Media

$\mathrm{HO}$ : the variance of the dependent variable is equal across groups (Homogeneous).

$\mathrm{H} 1$ : the variance of the dependent variable is different across groups (Not Homogeneous).

The criteria of hypothesis testing

If significant score $<0.05$, therefore, $\mathrm{H} 0$ is rejected and $\mathrm{H} 1$ accept

If significant score $>0.05$, therefore, $\mathrm{H} 0$ is accepted and $\mathrm{H} 1$ reject

From the table above, it showed that the significance of writing Skill was higher than $0.05(0.708>0.05)$. It means, that $\mathrm{H} 0$ is accepted and $\mathrm{H} 1$ is rejected. Therefore, the error variance of the dependent variable is equal across groups (Homogeneous).

Table 5 Descriptive Statistics Dependent Variable: Writing

\begin{tabular}{|l|c|r|r|}
\hline Media & Mean & Std. Deviation & $\mathrm{N}$ \\
\hline Experimental & 69.17 & 5.158 & 23 \\
Control & 65.13 & 6.483 & 23 \\
Total & 67.15 & 6.143 & 46 \\
\hline
\end{tabular}

The mean differences of writing skill for the two groups were:

1. The mean of writing skill using Web-Log was 69.71

2. The mean of writing skill using text book was 65.13

Based on the table above, there are differences in students' writing skills after being given treatments. The average results of the experimental class is 69.71, while the control is 65.13. It means that the post-test experiment is higher than the control. This shows that students who are taught using Web-Log have more significant influence on students' writing skills than students taught by textbooks.

Table 6 Contrast Results (K Matrix)

\begin{tabular}{|c|c|c|}
\hline \multirow{2}{*}{\multicolumn{2}{|c|}{ Media Simple Contrast ${ }^{\mathrm{a}}$}} & $\begin{array}{l}\text { Dependent } \\
\text { Variable }\end{array}$ \\
\hline & & Writing \\
\hline \multirow{6}{*}{$\begin{array}{l}\text { Level } \\
2 \text { vs. } \\
\text { Level } \\
1\end{array}$} & Contrast Estimate & -3.187 \\
\hline & Hypothesized Value & 0 \\
\hline & $\begin{array}{l}\text { Difference (Estimate } \\
\text { - Hypothesized) }\end{array}$ & -3.187 \\
\hline & Std. Error & 1.275 \\
\hline & Sig. & .016 \\
\hline & $\begin{array}{ll}95 \% & \text { Lower } \\
\text { Confidence } & \text { Bound } \\
\text { Interval for } & \text { Upper } \\
\text { Difference } & \text { Bound }\end{array}$ & -5.758 \\
\hline
\end{tabular}

a. Reference category $=1$

Based on the table above shows the contrast results using a simple method. Students who are taught using textbooks versus students are taught using Web-log with contrast estimation -3.187 and sig 0.016 . Therefore, The contrast made in this method has been improved because a significant score in contrast errors in the univariate test table was lower than $0.05(0.016<0.05)$.

Table 7 Univariate Tests

Dependent Variable: Writing

\begin{tabular}{|l|l|r|l|l|l|}
\hline & $\begin{array}{l}\text { Sum of } \\
\text { Squares }\end{array}$ & Df & $\begin{array}{l}\text { Mean } \\
\text { Square }\end{array}$ & F & Sig. \\
\hline Contrast & 115.430 & 1 & 115.430 & 6.249 & .016 \\
Error & 794.237 & 43 & 18.471 & & \\
\hline
\end{tabular}


The F tests is the effect of Media. This test is based on the linearly independent pairwise comparisons among the estimated marginal means.

Table 8 Pairwise Comparisons

Dependent Variable: Writing

\begin{tabular}{|c|c|c|c|c|c|}
\hline \multirow{2}{*}{\multicolumn{2}{|c|}{$\begin{array}{ll}(\mathrm{I}) & (\mathrm{J}) \\
\text { Medi } & \text { Medi } \\
\mathrm{a} & \mathrm{a} \\
\end{array}$}} & \multirow{2}{*}{$\begin{array}{l}\text { Mean } \\
\text { Difference } \\
(\mathrm{I}-\mathrm{J})\end{array}$} & \multirow[b]{2}{*}{ Std. Error } & \multicolumn{2}{|c|}{$\begin{array}{l}95 \% \\
\text { Confidence } \\
\text { Interval for } \\
\text { Difference }^{\mathrm{b}}\end{array}$} \\
\hline & & & & $\begin{array}{l}\text { Lower } \\
\text { Bound } \\
\end{array}$ & $\begin{array}{l}\text { Upper } \\
\text { Bound }\end{array}$ \\
\hline $\begin{array}{l}\text { Expe } \\
\text { rime } \\
\text { ntal }\end{array}$ & $\begin{array}{l}\text { Cont } \\
\text { rol }\end{array}$ & $3.187^{*}$ & 1.275 & .616 & 5.758 \\
\hline $\begin{array}{l}\text { Cont } \\
\text { rol }\end{array}$ & $\begin{array}{l}\text { Expe } \\
\text { rime } \\
\text { ntal }\end{array}$ & $-3.187^{*}$ & 1.275 & $\mid-5.758$ & -.616 \\
\hline
\end{tabular}

Based on estimated marginal means

*. The mean difference is significant at the .05 level.

b. Adjustment for multiple comparisons: Least Significant Difference (equivalent to no adjustments).

Based on the table above it showed that the mean differences of writing skill on both media were significant on the sign * were:

1. The students who are taught by using Web-log has significant score 0.016.

2. The students who are taught by using text book has significant score 0.016 .

Table 9 Tests of Between-Subjects Effects Dependent Variable: Writing

\begin{tabular}{|c|c|c|c|c|c|}
\hline Source & $\begin{array}{l}\text { Type III Sum } \\
\text { of Squares }\end{array}$ & $\mathrm{df}$ & $\begin{array}{l}\text { Mean } \\
\text { Square }\end{array}$ & $\mathrm{F}$ & $\begin{array}{l}\text { Partial } \\
\text { Eta } \\
\text { Square } \\
\text { d } \\
\end{array}$ \\
\hline $\begin{array}{l}\text { Corrected } \\
\text { Model }\end{array}$ & $903.698^{\mathrm{a}}$ & 2 & 451.849 & 24.463 & .532 \\
\hline Intercept & 1597.614 & 1 & 1597.614 & 86.495 & .668 \\
\hline Pretes & 715.676 & 1 & 715.676 & 38.747 & .474 \\
\hline Media & 115.430 & 1 & 115.430 & 6.249 & .127 \\
\hline $\begin{array}{l}\text { Error } \\
\text { Total } \\
\text { Corrected } \\
\text { Total }\end{array}$ & $\begin{array}{r}794.237 \\
209131.000 \\
1697.935\end{array}$ & $\begin{array}{l}43 \\
46 \\
45\end{array}$ & 18.471 & & \\
\hline
\end{tabular}

a. $\mathrm{R}$ Squared $=.532$ (Adjusted $\mathrm{R}$ Squared $=$ $.510)$

Based on the data above, it shows that the media score is lower than 0.05 $(0.016<0.05)$. Pre-test scores were significantly lower than $0.05 \quad(0.000<0.05)$. Therefore, in this ANCOVA model, the role of pre-test writing as a covariate is also effective. It means that this research succeded. However, the significant score of the pretest is also under 0.05 , the pretest as a covariate attenuates the use of Web-Log. It can be proven from the partial eta squared column that the pretest score is higher than the media, the pretest score is 0.474 and the media score is 0.127 or $12.7 \%$, Therefore, the success of this study was not only entirely influenced by the Weblog itself but it was also the students' pre-test skills when working on the questions. In other words the difference in writing skills, the average media use is not very significant. This means that web-log media have little variable influence on students' writing skills.

Hypothesis testing is done to find out the effectiveness of Web-log on student writing skills. Based on the above objectives, the researcher arranged the results of this study. The ANCOVA results from the $\mathrm{P}$ value $(0.016)$ were lower than alpha $(\alpha)(0.05)$. If the value of $\mathrm{P}<$ alpha $(\alpha)$, it means $\mathrm{Ha}$ is accepted and $\mathrm{HO}$ is rejected. In this study, researchers used a one-tailed test to find out the hypothesis.

H0: Students who are taught using online media have lower student writing skills scores than those who are taught using textbooks in learning English.

Ha: Students who are taught using Web-log has higher writing skills scores than those who are taught using textbooks in learning English.

It can be concluded that students who are taught through Web-log has better achievement in writing skills. But even though the score of experimental students is higher than the score of students in the control class, the success of significant scores or the success of Web-log in the experimental class is influenced by the other factors. Where this Web-log has been attenuated by the value of the pre-test as a covariate. So the Web-log only affects $12.7 \%$ of students' writing skills. 
Writing is one of the skills that are quite complicated to be learned by students in SMAN Bangkalan because of influencing factors. The data shows that some students have low grades in writing essays, because the students have difficulty in writing English essay and lack of ideas or understanding of what they want to write. In addition, they are always afraid of being wrong in grammar (Künne, 2012). From the data, we know that the pre-test score as a covariate is more influenced than the media used, thus weakening the use of Web-Log as media. It means that students' understanding of essay paragraph is already good, especially understanding of the generic structure (Lee, 2011). They also are easy to carry out commands when tests are given during the pre-test.

Even though the students have understanding of essay paragraph, they students still find the difficulty to get ideas when writing essay paragraph. Hence, the media used by researchers only affects by $12.7 \%$ to improve students' writing skills of the maintenance activities in the class.

\section{REFERENCES}

1. Karsak, H. G. (2014). The Effect of Using Cooperative and Individual Weblog to Enhance Writing Performance. Educational Technology \& Society, 229.

2. Künne, T. \&. (2012). Promotion of SelfCompetence in Kindergarten and Primary School. Gefördert durch: Niedersächsisches Institut für frühkindliche Bildung und Entwicklung / Forschungsstelle Begabungsförderung.

3. Latief, M. A. (2014). Research Methods on Language an Introduction. Maalang: Universitas Negeri Malang.

4. Latief, M. A. (2016). Research Methods on Languge Learning An Introduction. Malang: Universitas Negeri Malang.

5. Lee, L. (2011). Blogging: Promoting Learner Autonomy and Intercultural Competence Through Study Abroad. Language Learning \& Technology, 88.
6. Little, D. (1999). Learner Autonomy 1: Definitions, Issues and Problems. Dublin: Authentik Language Learning Resources Ltd.

7. Rudasill, D. S. (2011). Instruction at FSU: A Guide to Teaching and Learning Practices. Florida: The Florida State University. 